\title{
〔シンポジウム〕諸種疾患と糖蛋白質
}

\section{追加発言 1．動脈硬化とムコ多糖蛋白複合体*}

\author{
木 本 英 治**
}

現在, 硬化症発現の機序として多くの支持を得ている 学説として，血栓原性説，脂質汇過説，血漿浸潤説又は 内膜浮腫説があるが，これらは血漿蛋白質成分の動脈壁 内への異常透過を重要視している.

最近に乱ける，結合織内ムコ多糖に関する知見による と，一般にムコ多糖は共有結合により core protein と結 びついた proteoglycan の形で存在し，更にそれに非共有 結合により糖蛋白質 (bridging protein ${ }^{1)}$ 又は link protein ${ }^{2)}$ ) がから久あって巨大分子 protein-polysaccharide complex (PPC) を形成しているとみなされている.

動脈壁のムコ多糖が過去約20年間にわたり，生化学的 及び組織化学的に研究され，硬化症発現に打けるムコ多 糖の関与の仕組みについて，いろいろの機序が考光られ て来た. ${ }^{3}$ 乙かし, 生化学的には蛋白成分から切り離さ れたムコ多糖部分のみが研究の対象とされ，組織化学的 飞は多糖鎖の末端付近の官能基に対する染色性のみが取 り披われて来た。

著者はさきに，ヒト大動脈より，グルコース含有の糖 蛋白質を分離し，これが臟器特異性を有すること，ムコ 多糖特にヒアルロン酸と 結びついて巨大複合体を形成 し, hyaluronidase 消化により分子量数万程度のものに 低下することを報告した。市

本実験に括いては，ヒト大動脈を $3 \mathrm{M}, \mathrm{MgCl}_{2}$ で抽出 し，エタノールを加えて沈殿する粗製 PPC につき， $\mathrm{C}_{\mathrm{S}} \mathrm{Cl}$ 密度勾配遠心を行ない，大部分のムコ 多糖部分は
底に沈降するに対して, 上記糖蛋白質は水面近くに浮上 することを認めた，従って，当該糖蛋白質は bridging protein ${ }^{11}$ に相当するものであるとみなされる.

大動脈 PPC の粘度は hyaluronidase, proteașe 又はフ リーラジカル（極少量の $\mathrm{H}_{2} \mathrm{O}_{2}, \mathrm{Vc}$ 添加）により著しく 低下した。

大動脈 PPC は，フィブリノーゲンの 沈降速度を著し く低下させる作用のあることを認めた．上記の崩壞し たPPCではこのような作用は減弱した. 従って, 大動脈 PPC が, 血漿蛋白質の動脈壁内拡散を扣さえる diffusion barrier ${ }^{5)}$ としての役割を演じているとみなした。

螢光抗体法による当該糖蛋白質の動脈壁内分布を調べ た成績によると（久留米大・医・第 2 病理・栗飯原によ る)，正常内膜では内皮細胞及びその直下の部位に限局 して濃厚な營光がみられ, 内膜の diffusion barrier とし ての位置を占めていることを示した。

\section{文献}

1) Dunstone, J. R. and Franek, M.D. : Biochem. Biophys. Res. Commun. 27, 39 (1967).

2) Rosenberg, L. et al. : J. Biol. Chem. 245, 4123 (1970).

3）木本英治：䛦療 17, 1494（1964）.

4) Kimoto, E. et al. : J. Biochem. 66, 369 (1969).

5) Laurent, T. C. and Pietruszkiewicz, A. : Biochim. Biophys. Acta 49, 258 (1961).

* Arteriosclerosis and mucopolysaccharide-protein complex.

** Eiji Kimoto, 久留米大学医学部臨床病理研究所 (現在 福岡大学理学部化学教室). 